\title{
Arquitetos e viajantes
}

Em seu segundo ano, é com prazer que apresentamos aos leitores a quarta edição da revista RuMoRes. Além dos artigos, a partir deste número temos também uma novidade na estrutura de nosso site: redesenhado para atuar de forma dinâmica, sua nova organização permite a busca dos textos por categorias: autores, palavraschave e também por edição, contemplando assim recursos próprios dos meios digitais nos modos de navegação e acesso à revista.

$\mathrm{Na}$ nova estrutura há mais mudanças, dentre as quais destacamos a possibilidade do leitor deixar seus comentários nos artigos (depois de aprovados pelos editores); o envio de artigos para publicação por meio do site; e uma inovação ainda rara em revistas digitais: não mais organizada a partir de sumários rígidos que reproduzem os periódicos impressos, a revista RuMoRes propõe uma outra forma de produção e recepção de publicações online.

Essa abertura se observa em pelo menos dois sentidos: primeiro, por possibilitar a recuperação dos artigos de forma não-linear, independente da edição em que foram originalmente publicados. Segundo, por permitir ao leitor criar seu próprio trajeto de navegação. Além disso, não sendo determinada por padrões característicos das revistas tradicionais, RuMoRes publicará os artigos aprovados para a edição atual mensalmente, estabelendo um fluxo contínuo de recebimento, avaliação e divulgação dos textos. No final do semestre, o conjunto de artigos publicados ao longo dos meses estará reunido na edição corrente (que poderá ser acessada em sua totalidade por meio da busca por edições), ou poderá ser visualizado em relação a outros textos já publicados (por meio das ferramentas de busca por autores e palavras-chave).

As características dinâmicas, portanto, não se fazem notar apenas na concepção da revista ou em sua sofisticada arquitetura, mas também nas formas de acesso e uso, estabelecendo canais efetivos de interlocução entre autores e leitores. Esperamos que os navegantes de agora e do futuro gostem do novo site e contamos com o envio de artigos, comentários e sugestões.

Nesta primeira edição de 2009, apresentamos um conjunto de textos ao mesmo tempo heterogêneo e coeso, atravessando diversas áreas de estudo e objetos que emprestam ao campo da comunicação suas especifidades. Sem querer determinar uma ordem rígida de leitura, apresentamos aqui um possível roteiro de viagem entre os artigos publicados.

Os textos do Dossiê têm como eixo comum, sob diferentes abordagens, o campo da política em suas relações com a sociedade. Tratando de objetos diversos - as interações entre jornais impressos e veículos online no âmbito da comunicação política, a pluralização das fontes de informação política, a censura política em peças teatrais -, as contribuições de Juliano Borges, Cristiane Bernardes \& Antonio Teixeira de Barros, e de Mayra Rodrigues Gomes \& Ferdinando Martins fornecem elementos diversos para o estabelecimento e problematização das relações entre mídia e política na contemporaneidade.

Na seção Artigos, temos um conjunto de dez textos que se distribuem por teorias e metodologias variadas, construindo um mosaico do campo de estudos da comunicação na atualidade. Estratégias de comunicação, discurso publicitário, crítica literária e cinema são alguns dos possíveis eixos articuladores dos artigos, apontando recorrências em sua diversidade.

Carlos Renan Sanchotene e Viviane Borelli apresentam reflexões sobre o processo de midiatização do campo religioso, enquanto Verena Pereira trata da questão das estratégias de comunicação do programa de incentivo estatal à produção de documentários brasileiros. 
Sobre o discurso publicitário, o primeiro texto, de Wilma Rigolon e Edson Silva, também aborda a questão das estratégias comunicacionais presentes em slogans de natureza verbal, enquanto Carla Daniela Rodrigues aponta as estratégias discursivas em anúncios voltados para o público jovem. Raquel Ribeiro, por sua vez, analisa como se dão as identificações dentro do cenário da midiatização, por meio de representações sociais presentes em campanhas publicitárias.

A crítica literária ganha destaque nessa edição por meio de três artigos: o primeiro, de Carolina Figueiredo, aborda a questão do autor sob a perspectiva da análise do discurso, definindo-o como sujeito influenciado pelo contexto histórico e pelo discurso do Outro. No segundo e terceiro artigos, tomamos a interface entre cinema e literatura sob duas perspectivas: apontando algumas das relações existentes entre o filme e o livro Memórias do Cárcere, no texto de José Eduardo Bozicanin, também sob a perspectiva da análise do discurso; e a partir da investigação sobre como o cinema brasileiro apropriou-se de fontes literárias na elaboração de seus filmes, em contribuição de Marcel Vieira Barreto Silva.

Nos dois últimos artigos é o cinema que se afirma como espaço privilegiado não apenas para os estudos de audiovisual, mas também para refletir sobre as mídias e a sociedade contemporânea: o artigo de Marina Soler analisa as construções imagéticas e sociológicas presentes no filme Terra estrangeira, e Maria Ignês Magno aborda a produção crítica de Jean-Claude Bernardet e os diálogos que estabeleceu com a história e a cinematografia brasileira nos anos de 1960.

Finalmente, as Resenhas de Renata Costa e Juliana Doretto trazem perspectivas históricas e utópicas sobre o jornalismo, buscando compreender seu fazer atual a partir de um passado consolidado que se projeta para um futuro transformado pelas mídias digitais online. Fecha-se, assim, um ciclo e surge um recomeço, articulando os textos desta edição não por meio de respostas coerentes, mas de desafios multifacetados.

Como nas metáforas de Lúcia Leão sobre os navegantes do ciberespaço, esperamos que todos, arquitetos ou viajantes, possam percorrer as palavras e imagens de RuMoRes e chegar a novos e sempre possíveis caminhos.

Rosana de Lima Soares 